\title{
Perspective
}

An occasional series in which contributors reflect on their careers and interests in psychiatry

\section{Festina Lente}

HeNRY R. ROLLin

It is a sobering thought that, if Latin had been included in my clutch of credits when I matriculated, I might today have been a retired schoolmaster, or whatever a modest degree from a provincial university would have fitted me for. My interests were, and if truth be told, have continued to be, in the arts. Since childhood I have been awed by the power and beauty of language and have sweetly savoured the subtlety of words. I have read voraciously, an activity encouraged by my father, one of nature's scholars, himself a bibliophile and linguist. Every nook and cranny of every house we ever lived in he filled with books in English, Russian, Yiddish and Hebrew, apart, that is, from a very considerable and valuable collection of memorabilia concerned with the early history of socialism and trade unions, particularly Jewish trade unions, now deposited with Warwick University.

Leeds, where I spent my formative years, had at least one redeeming feature: it buasted in those days a host of theatres including The Royal and the Grand, both deserving of their grandiose names, and both considered eminently suitable for productions on their way to, or from, London.

For a modest sixpence I had access to the best the English theatre had to offer, and there can have been few established or rising stars who have not fallen within my gaze from my position of vantage in the 'gods'. I remember, for example, circa 1930, a presentation of Private Lives, the cast of which included the playwright himself, Noel Coward; Laurence Olivier, Adrianne Allen and Gertrude Lawrence, and I recall drooling with delight as these magicians conjured a ton of entertainment out of an ounce of dramatic puffpastry.

If I was endowed with any talent at all it was as a writer. I can hardly remember a time when I failed to feel an involuntary tingle of excitement tinged with apprehension when faced with a blank sheet of foolscap. Not that writing comes easily: I am too obsessional for that, so anything I have ever written has, as a result, been subjected to many drafts and continued revision. It was this quirk, incidentally, ignorance apart, which militated against the completion in time of any written examination I have ever sat.

But it was Latin, or the absence thereof, that did me down. No Latin; no admission to the Faculty of Arts. What then was the alternative? My father, noble soul that he was, had always wanted me to be a doctor, a profession he saw to be honourable and compatible with his decidedly left-wing political views. I was finally persuaded; and with minimal enthusiasm I enrolled in the Faculty of Medicine of Leeds University in 1929.

At best I was an indifferent student, not because I was particularly dim, but because I had not the slightest interest in what I was called upon to study. There was not a single subject in the curricula for the First or Second MB examinations that appealed to my heart or mind. Rote learning, that painful acquisition of knowledge without thinking, was anathema to me. There was no scope for what I considered to be the very essence of a University, that is, the right to challenge one's teachers, or to think differently.

But the Rubicon had been crossed. The financial investment in me was too great even to contemplate a switch in direction. I worked-when I worked-without inspiration and without joy. I managed to maintain my equilibrium, however, by my extra-curricular activities. My devotion to the theatre had continued, but to this I had added music and the opera, all, that is, within the constraints of my meagre weekly allowance. I kept abreast of contemporary literature, but found myself more and more seduced by American writers, particularly by that incomparable galaxy of humourists, Don Marquis, Damon Runyon, James Thurber and S. J. Perelman. My debt to Mr Perelman, incidentally, is substantially enhanced in the knowledge that he was responsible for some at least of the scripts of the Marx Brothers who, at that time, became a cult of which I was (and remain) an unashamed votary.

Life took on a somewhat rosier complexion when clinical work began. I was intrigued (and still am) by the problems of clinical diagnosis which, for their solution, demand the joint talents of a craftsman, an historian and, fortunately for me, only minimally that of a scientist.

I eventually qualified, but the most assiduous of researchers would fail to find my name on any Honours Board, or in any list of prizemen; although it could be found in the cast-list of various University theatrical productions 
and as the author of occasional contributions to University publications.

The family fortunes at that time were at their lowest ebb and the immediate imperative was to earn money. In those days there was no legal obligation to do post qualification house jobs, but I felt morally obliged to augment my scant student experience with some work in hospital. However, payment was essential, and the amount one was paid was inversely proportionate to the prestige of the hospital. The General Infirmary at Leeds, for example, paid its housemen nothing beyond their keep, not that I had a cat-in-hell's chance of being appointed to the House, taking into account my track-record as a student and the anything but covert antisemitic policy then pursued. But I did succeed in getting a job at the Oldham Royal Infirmary which served my purpose excellently.

Then what? Specialisation requiring higher qualifications was out of the question for a variety of reasons, not the least of which was my low self-esteem, academically speaking at any rate. To tide things over, locums in hospitals, both general and mental, or in general practice, were fairly readily available. And so for a time I wandered the country as a medical gypsy using the family home, by then in London, as a base. I learned little psychiatry in my wanderings, but what I did learn was that as a junior medical officer in a mental hospital, the work was light, the time-off generous and the standard of living inordinately high.

My experiences in general practice were extraordinarily varied and ranged from mercifully short locums in sweatshop practices in London's East End to one lasting several months in a smart West End practice which offered the use of an elegant flat, to boot. The added attraction of this particular job was that, included among the list of patients, were several employed in the theatre in one capacity or another, through whose good offices I could go to as many matinees as I had time for, or to evening performances when the house needed a little 'papering'. But at no matter what level, I had become convinced that general practice of the one-man sort was an unmitigated form of drudgery and/or slavery and not to my liking, although, on reflection, an alternative was difficult to visualise.

I felt cornered: and it was then that I decided to throw discretion to the winds and to indulge in an act of inexcusable self-indulgence. I applied for and, within a week, was offered an appointment with the Blue Funnel Line as a ship's surgeon. So it was that towards the end of 1937 I sailed from Birkenhead in the $M V$ Memnon on a voyage lasting six months calling at ports strung like precious jewels half way round the world to Japan and back, ports of call which hitherto had seemed as inaccessible as the topmost peaks of the Himalayas.

From a professional standpoint it was unadulterated lotus-eating, but no matter what guilt feelings I allowed myself to entertain at the time I would not, in retrospect, have missed the exotic experience, an experience so rich that it has fuelled my imagination ever since.
I wish I could say that my choice of psychiatry as a speciality was determined by some inner, irresistible, driving force. I was certainly driven, not by desire however, but by dire necessity. An advertisement appeared in the British Medical Journal for Assistant Medical Officers in the London County Council Mental Hospitals Department which, at that time, was efficient, prestigious, powerful and, seemingly as eternal as Imperial Rome. I was not slow to realise that such a job offered, not only a career structure but for me, hedonist that I am, the additional advantages of proximity to London and a standard of living comparable with that I had enjoyed as a ship's officer. I applied, and to my intense relief was appointed, but, as I discovered, a successful candidate was appointed to the Department and not to a particular hospital. That came later; and it came about by a process of allocation which was then, and has remained ever since, shrouded in mystery. It was rumoured, however, that the least promising appointees were allocated to mental subnormality hospitals; and to such a hospital was I allocated, to wit, to Caterham Asylum as it was known, before it was canonised and became St Lawrence's Hospital.

Assistant medical officers were in all respects probationers. Retention in the service for longer than three years was contingent, according to the LCC Book of Rules, on "securing a degree or diploma in psychological medicine and upon the submission of a definite report by the medical superintendent that you have shown yourself entirely suitable for consideration in due course for promotion". The first leg of this dictate depended on one's own efforts; but to satisfy the second, one was at the mercy of the medical superintendent who, in my case, was an ignorant pig-headed bigot whose sole claim to psychiatric distinction lay in the possession of the FRCS (Ed).

Fortunately for me, the said FRCS (Ed) showed not the slightest interest, and took no part, in the clinical work of the hospital. This he left to his deputy, a very remarkable, patrician Dubliner, Charles James Cecil Earl. Earl was the first of a long string of teachers of first class importance who took an interest in me and who, singly and together, had such a profound influence on my career.

Earl was himself something of an iconoclast and he took kindly, therefore, to my iconoclastic observation that, of the $\mathbf{7 3}$ mongols in the hospital, singularly few conformed to the accepted textbook description of their personality characteristics as portrayed by D.J. Langdon Down in 1866, a portrait which had automatically been repeated in the literature from then on. Furthermore, it seemed to me that a considerable proportion of our mongols, particularly those in the lowest intellectual categories, were by any standards psychotic and approximated to a syndrome first described by Earl as 'Primitive Catatonic Psychosis'. With Earl's encouragement I began my first research project which was accepted by Leeds University as a fitting subject for an MD thesis.

I now had a raison d'être, professionally speaking, and my new-found enthusiasm was considerably heightened by the stimulus I received from attending a mandatory day 
release course at the Maudsley, then the flag-ship of the LCC Mental Health Service.

In the late 1930s the Maudsley, as a centre for psychiatric postgraduate teaching, was at its zenith. The academic staff was as star-studded as the cast-list of the National Theatre. Such excellence was due in no small measure to the intellectual windfall that had come its way as a result of the Nazi holocaust. Among those who had found sanctuary at the Maudsley were Alfred Meyer, Willi Mayer-Gross and Erich Guttmann. All these great men were my teachers, together with home-grown worthies such as, for example, Frederic Lucien Golla, C. P. Blacker, and the twin brothers, Eliot and Patrick Slater, not forgetting the redoubtable (Sir) Aubrey Lewis, if the concept of 'home-grown' can be extended to the Antipodes.

The inordinately high standard of psychiatric teaching was paralleled by that available in neurology at Maida Vale and Queen Square, so that not to have passed the DPM, the object of the exercise, would have been careless, if not positively indecent. An additional carrot, if such were needed, was the automatic bonus of $£ 50.00$ per annum, a sizeable sum in those days when a pair of hand-made shoes cost three guineas.

The outbreak of war in September 1939, not surprisingly, upset the even tenor of life at Caterham, particularly so when the phoney war, the Sitzkrieg, was succeeded by the Blitzkrieg. Strategically speaking we were most unfortunately situated, lying as we did between the Guards' Depot next door and RAF Kenley a mere thousand yards away, both of which could be considered as legitimate military targets. It required only a little inaccuracy in the aim of the Luftwaffe bombers for us to become inadvertently the target for tonight. It happened not infrequently; and a pretty terrifying experience it was, to be sure.

In view of the deteriorating military situation official policy had to be changed so as to allow doctors employed in hospitals in and around London, hitherto 'frozen', to join the armed forces. I was the first in my hospital to be 'unfrozen' and was commissioned in the RAF VR in June 1941. Sacrilegious as it may sound, I enjoyed my war if for no other reason than, to begin with, it meant exchanging the nightly terrors of the Blitz for the deep-deep peace of a plush RAF mess in the heart of the Cotswolds.

Psychiatry as distinct from, or complementary to, neurology, came to be recognised in the RAF in the early 1940s. The likes of me, when it was discovered that we had some psychiatric experience and held the DPM, were winkled out from general duties and deemed 'neuropsychiatrists', and as such I was employed for the major part of my service. As a specialist I worked cheek-by-jowl with some of the most distinguished physicians of the day, and in particular with Sir Charles Symonds, one of my illustrious teachers at Queen Square, and the ill-fated R. D. Gillespie of Guy's, who headed the psychiatric limb of the combined speciality. It was Dr Gillespie, incidentally, who encouraged and supervised me in the various research projects I undertook and who vetted my manuscripts before the papers were submitted for publication.

My debt to the RAF is incalculable. Professionally speaking I acquired an enormous experience, particularly in the understanding and treatment of psychological stress with its protean manifestations, an experience which was to stand me in such good stead when I helped to man the newly-founded out-patient clinics on my return to "civvystreet'. Not only this, but as I rose in the RAF hierarchy I learned to shoulder responsibility and to command rather than be commanded, a lesson by no means of inconsequen. tial importance.

It was for those very good reasons that when, in 1947, I returned to the service of the LCC as a 'second medical officer', a considerable step-down from the rank I had enjoyed in the RAF, it was not without a modicum of regret. I was posted to Cane Hill Hospital, Coulsdon, where I had the exceedingly good fortune to work under Alexander Walk who became, not only my boss, but my mentor and friend. From him I learned a great deal of clinical psychiatry, but more importantly, I was able to soak up, almost by a process of osmosis, some of his profound reverence for antiquarian books as well as some of his enthusiasm for medical history.

Perhaps inspired by Walk, or goaded by my demotion, I buckled down to work and succeeded in completing the MD. Armed with this higher qualification promotion came relatively quickly. A year to the day after I began at Cane Hill I was transferred on promotion to Horton Hospital, Epsom, as a 'First' and not long afterwards moved up to Physician Deputy Superintendent-but not for long. With the advent of the NHS in 1948 the old hierarchical order changed: I was graded as a Consultant and such I was to remain until my retirement in 1976.

Horton, at the time I was appointed to the staff, was in a state of transition. Throughout the war, and for two or three years afterwards, it had rendered yeoman service as an Emergency Medical Service hospital, catering for military and civilian casualties. That job done, it had perforce to revert to its role as a psychiatric hospital.

In effect, Horton was starting from scratch, and the staff were in the unique position of being able to incorporate in the hospital's development ideas which stemmed from the changing and more enlightened approach to the mentally disordered. In essence this was a determined move away from the prison-like state of affairs which had previously existed and which was deemed necessary in order to contain patients, almost all of whom were held under compulsory orders, in spite of the provisions in the Mental Treatment Act, 1930, which for the first time had permitted their admission on a temporary or voluntary basis. In keeping with the new enlightenment greater attention was paid to the clothing worn by patients and to their physical environment. There was a swing away from the drab ill-fitting suits and dresses of yesteryear, all of which had a workhouse flavour. More imaginative colour schemes were devised for both the wards and the corridors, a welcome relief from the 
erstwhile ubiquitous dark chocolates and oleaginous greens. Similarly, yesterday's too-too solid furniture, built not for comfort but for durability, gave way to something lighter and more comfortable.

Accompanying this transformation in the physical environment in which the patients lived came a determined move to counter the enforced idleness which had been one of the worst, and one of the most cruel, features of Britain's pre-war mental hospitals. A whole range of activities (call them 'therapies' if you wish) was introduced including occupational therapy which was later transmuted, unhappily perhaps, into industrial therapy. At Horton, we added in turn music, art and drama 'therapy' for which we were lucky enough to be able to recruit experts in the field as therapists. It is in the context of music, however, that Horton achieved a national, if not international, reputation. We were able to mount concerts by patients, which were designed not only for the entertainment of patients from our own and other hospitals. In addition they served as an integral and much appreciated feature of the annual meetings of our League of Friends, one way, indeed, of repaying our debt to these stalwart supporters. On one memorable occasion Horton acted as a venue for a meeting of the Osler Club of London. I read an introductory paper on Music Therapy which was followed by a concert. It was noted later in the discussion that for the very first time in the Club's history it was patients who had acted as hosts and who had provided the entertainment.

It is an intriguing, and to me inexplicable phenomenon how, symptomatically, the pattern of madness has changed in my lifetime. In the 1930s a goodly proportion of patients in mental hospitals still exhibited gross and/or bizarre manifestations of their illness. There were schizophrenics, for example, who spent their entire day in assumed statuesque postures; others who endlessly carried out strange and seemingly meaningless rituals, or who rocked rhythmically and tirelessly backwards and forwards in their chairs. Cases of flexibilitas cerea were easy to come by. Others showed grossly depraved behaviour, such as faeces-eating or smearing, and others still filled their day in open and unashamed masturbation. A particular management problem was to be found in the schizophrenics who ranged through the catatonic spectrum from a state of wild excitement to one of stupor. Where are they now?

Comparably, in those deemed to be suffering from the affective psychoses, there was no shortage of cases of maniacal excitement, or of depression so profound as to lead to stupor, both conditions which could be regarded as a threat to life. Forced feeding of these unfortunates was a well practised technique. These were the days, too, of the infamous 'Suicidal Caution Card', a document every member of staff involved in the patient's treatment was obliged to sign. Writ large in red lettering was the command that the patient 'must on no account be allowed out of observation, not even in the WCs'. And so for these anguished, guiltridden, self-accusatory wretches even the privacy of the privy was denied them. Where are they now?

It is quite possible, of course, that the dramatic change in the face of madness was a function of the change in the atmosphere in mental hospitals. This in turn had gone hand-in-hand with the change in the therapeutic climate which had swung from the despairing nihilism of the 1930s to the ever-increasing optimism of later years. I was a witness of, and indeed, actively participated in, all these changes, particularly after I took a hand in developments at Horton after 1948. This was the era of Sargant and Slater, the high-noon of physical methods in psychiatric treatment; the days of ECT, 'straight' and later 'modified', of deep insulin clinics and, heaven forgive me, of pre-frontal leucotomy.

These were heady days for psychiatrists who, like myself, were still in the main mental hospital based. Optimism rode high, so high, in fact, that we were convinced that the psychiatric millenium was just around the corner. But rationality eventually re-established itself: we awoke from our wish-fulfilling dream to the realisation that what we had unwittingly been witness to was a variation of the oldest morality play in the repertoire-The Emperor's New Clothes. By the mid-1950s the deep-insulin clinics had been dismantled, the flood of pre-frontal leucotomies had been reduced to the merest trickle, and ECT, the sole survivor of the grande époque, was to find its major usefulness, not in the treatment of schizophrenia, but in the affective disorders, particularly in depression.

It was fortunate for our punctured morale that, just about this time, perhaps the most important revolution in the history of treatment in psychiatry was taking place. I refer, of course, to the era of psychopharmacology. On the principle of 'once bitten, twice shy' I had (and still have) reservations about the use of these highly potent and toxic drugs; and in particular their effect on prognosis in the long term.

It is a curious irony that at the very time that British mental hospitals were enjoying their greatest international fame, the seeds for their destruction were being sown. In 1961 papers appeared by different authors forecasting that, as the result of statistical analyses of current trends, the future need of beds in British mental hospitals would be halved. Undoubtedly influenced by these prognostications, the then Minister of Health, Mr Enoch Powell, published, in 1962, his Hospital Plan wherein he pronounced that, within ten years, half our mental hospitals would be pulled down and their function split between community agencies and general hospitals. I was, and still am, highly critical of the plan and of the statistics on which it was based. I believe, and have oft repeated my belief in print, that "community care' was, and is, little more than a talismanic catchphrase. The fact that at this very moment, 25 years on, there is a public outcry concerning the lack of facilities in the community for the care of discharged psychiatric patients would tend in some measure to justify my scepticism.

I have often been outspoken in my opinions, no matter how controversial they may have been, but never have I been so vitriolic as I was in a letter published in the $B M J$ in 1961 criticising one of the papers which had swayed the Minister of Health. The letter was published in extenso and 
occupied a full page. It brought forth a great deal of wrath, but also some earnest praise from people whose opinions I respected. But, be this as it may, the letter paid unexpected dividends in that it marked for me the beginning of a secondary career, namely, as a medical journalist. I had previously published a fair number of papers in various journals on subjects varying from the use of music and art in treatment to one on myxoedematous madness. From 1961, however, I was taken up by the $B M J$ as a leader writer, book reviewer and literary odd-job-man. Work for other journals quickly followed so that for the past 25 years or more I have hardly ever been out of print. And never have I felt more fulfilled. There is nothing like being commissioned to write an editorial on a given subject to concentrate the mind most wonderfully; and to be asked to review books is a way of keeping abreast of the literature and augmenting one's library, if not one's income. But the privilege and pleasure that I treasure beyond measure was to have contributed on a regular basis to World Medicine in the golden years of Michael O'Donnell's editorship. It must then have been the most widely read and most enjoyed medical journal in the UK and it was, incidentally, the first medical journal to pay its contributors something approaching the rate for the job. I still mourn its premature and, apparently, unnecessary demise.

The USA has always held a fascination for me. In my formative years I was much influenced by its movies, its playwrights, its novelists, and, as I have already indicated, its humorists. Next to the Marx Brothers I identified most closely with Damon Runyon's loveable rogues. For years I had harboured a burning ambition to eat cheesecake at the source, at Mindy's on Broadway, where, I was convinced, I could meet up with Harry the Horse, Dave the Dude, Good Time Charley, or other of my disreputable heroes.

I was sufficiently circumspect, however, not to mention this ambition when, in 1953, I applied for a Fulbright Fellowship. I succeeded in my application, and on arrival in the USA, I lost little time in realising my fantasy. To my disappointment I was unable to identify positively any of Runyon's celebrities, but there were a dozen or more who were highly suspect. But if there was a modicum of doubt about the identity of some of the customers there was absolutely no doubt about the quality of the cheesecake.

But the realisation of a young man's fancy was not the sole object of the exercise. I had been deeply impressed by the work of Drs Edward Weiss and O. Spurgeon English in the field of psychosomatic medicine, and it was under them that I had elected to study, and it was to their hospital, Temple University Hospital, Philadelphia, that I made my way. Included in the academic package was a shortish stint at Johns Hopkins Hospital, Baltimore, considered in those days as the finishing school for British psychiatrists. But by the time I arrived, the Commonsense Psychiatry of Adolf Meyer had given way to the more esoteric formulations of the psychoanalysts.

Although I enjoyed my stay in the States enormously, I would be hard pressed to detail what I actually learned, psychiatrically speaking. Nevertheless, in a negative way I am deeply indebted to my American experience. I learnedand this was a lesson I needed to learn - that psychoanalysis with which, like most embryo psychiatrists, I had flirted for some years, was not for me. America, when I was first there, was in the grip of a veritable epidemic, almost a plague, of psychoanalysis and Temple was indeed a temple dedicated to the greater glory of Freud and the Freudians. Clinical meetings at which, incidentally no patient was ever presented, were pervaded by something approaching an odour of sanctity, and the hair-splitting arguments on points of dogma that ensued were just as heated and inconclusive as those, I imagine, which enliven debates amongst Jesuits or Talmudists. It was during one of these stormy discussions that, try as I might, I could no longer suppress my schoolboyish giggles at a point when some particularly outlandish interpretation had been made. The effect was electric. The chairman glowered at me and in a voice tinged more with anger than with sorrow, growled, "Henry, it may be a joke to you, but to us it's a religion." And that's precisely what it was; and that's precisely why I wished no part of it.

For a variety of reasons I have visited the States several times since, and I have been struck by the continuing decline in the importance of psychoanalysis as a therapeutic procedure. Could it be that in the USA, as in the UK, the parable of the Emperor and his new clothes had had its impact?

My career took an entirely unpredictable turn as a result of the implementation in November 1960 of the Mental Health Act, 1959, and in particular, Part IV of the Act which dealt with the mentally abnormal offender. Horton, by virtue of the social pathology of its catchment area, admitted more offenders under Hospital Orders (Section 60) or under Place of Safety Orders (Section 136), than any other hospital in the UK. I soon had reason to question the validity of some of the premises on which this particular part of the Act had been based and, by way of proof, I published a series of papers in which I analysed the data I had accumulated.

It was these papers that served as my apprentice's diploma entitling me to be admitted to what was then a small, select guild of forensic psychiatrists or 'psychopenologists', as I have heard them called in the States. My acceptance as a forensic specialist paid rich dividends. I was appointed as a medical member of the Mental Health Review Tribunals at the time they were set up in 1960 until age with stealing steps signalled my retirement in 1983. By the same token I was appointed to the Parole Board on which I served from 1970 to 1973 , over three years of hard labour made eminently worthwhile by the opportunity it gave me to sharpen my wits on the whetstone of some of the leading legal luminaries of the day. However, far and away the most valuable dividend was my election in 1963 to a Research Fellowship at Nuffield College, Oxford. This was an experience priced far above rubies, affording me, as it did, the opportunity to write my book, The Mentally Abnormal Offender and the Law, the framework of which $I$ had laid down in my earlier papers. At 
Oxford I worked in close association with the Department of Criminology, then headed by Nigel Walker who, shortly afterwards, was to become Professor of Criminology at Cambridge. Not only this, but I was able to savour the delights of the Olive Grove of Academe and compare them ruefully with the intellectual sterility of my days as an undergraduate at Leeds.

Finally, in order to demonstrate that there is no need to wither on the vine after retirement from the NHS, I would mention that for the past nine years or so I have, in the main, been pleasantly and gainfully employed as a Consultant Forensic Psychiatrist to the Home Office, an opportunity sadly afforded by the tragic and premature death of Peter Scott. My base is HM Prison, Brixton, but as a spin-off, in the guise of an expert witness, I have given evidence in almost every court at the Central Criminal Court, Old Bailey, and been cross-examined by most of our eminent criminal lawyers.

This is not always a pleasant experience-far from it. I appreciate, of course, that it is an accepted tactic of counsel to discredit witnesses, but this is a far cry from deliberately humiliating them which is what certain of the Old Bailey bully-boys set out to do, and so often succeed in doing. Nor is this difficult as things stand: the fragile discipline of psychiatry is no match for the heavyweight onslaught of the lawyers. To survive as a forensic psychiatrist, therefore, demands nimble wits and a very tough hide indeed.

My career in psychiatry has been played out against the backcloth of the old RMPA and later the College. I joined the RMPA in 1939, but was content with bit-parts until 1957 , when I joined a study tour of Israel, thereby, incidentally, fulfilling a lifelong ambition. Edward Stern was then the secretary of the Study Tour Sub-Committee, and it was on the Secretary that the organisation of such tours devolved-and still does! After Israel, Edward felt that he had done his stint and resigned. For the life of me I can't remember how it came about, but somehow I was landed with the job. It's a job not without responsibility, but there are compensations in that it gives scope for some degree of self interest. It falls to the Secretary to choose the venues for the tours: I chose Denmark, France, Mexico (coinciding with a meeting of the WPA) and Italy, all of them high on my own list of priórities.

I would add, en passant, that study tours have proved themselves to be some of the most important and successful ventures of the College, promoting, as they do, international understanding and goodwill; and yet, I regret to say, they have never been fully appreciated or patronised by the top-brass.
If I am vague as to how I became Secretary of the Study Tour Sub-Committee, I am even more vague as to how I became Librarian. Denis Leigh, my predecessor, resigned in 1975 and I suspect that I was approached and agreed to stand for the office. I further suspect that I was unopposed, and, was, therefore, duly elected. But I could be wrong.

By this time the College had taken over its present premises at 17 Belgrave Square, the first time that it, or its precursors, had had a home of its own. The assembly of the Library, hitherto languishing in a host of crates in the cellar, bristled with difficulties. The floor of the elegant room on the first floor, chosen to house the 5,000 or more books and ephemera, was deemed to be insufficiently strong to bear the dead weight. It would have to be lifted and steel girders inserted underneath. The shelving and bookcases brought from Chandos House, our previous temporary home, were hopelessly inadequate and new ones had to be designed and built. Similarly, new furniture, curtains and carpets had to be selected, all within the constraints of a limited budget. It all took time and an infinity of patience, but we got there in the end. I say 'we' for the simple reason that it could never have been accomplished without the help of our first professional librarian, Mrs Susan Floate.

My librarianship for the decade 1975-1985 was perhaps the most rewarding period of my life. It was singularly gratifying to have witnessed, and to have made a contribution towards, the culmination of an evolutionary process which began late last century in the shape of a collection of books only sufficient in number to fill a simple, borrowed bookcase when the Medico-Psychological Association rented accommodation on a part-time basis from the London Medical Society at 11, Chandos Street, W1.

For myself, there was the added, almost sensual, gratification the bibliophile experiences in handling antiquarian books. There was the added delight, in this particular instance, of knowing that most of our volumes had belonged to and bore the signatures of, some of our most illustrious predecessors, men who have become part of the folklore of our specialty.

I became, as my readers will have gathered, a doctor not by choice, and a psychiatrist faute de mieux; all in all, not the most propitious foundation on which to build a career. And yet it is only in psychiatry perhaps that it could have worked out as well as it has done. Psychiatry, as I discovered, spills over into so many other disciplines that it affords a golden opportunity for the dilettante-which is essentially what I am-to flourish.

But no matter what, I am in no way dissatisfied with the course my life has taken which, but for the throw of the dice, might have been so different. 